\title{
The Optical Absorption of Gamma Irradiated and Heat-Treated Natural Quartz
}

\author{
Eduardo Henrique Martins Nunes, Fernando Soares Lameiras* \\ Centro de Desenvolvimento da Tecnologia Nuclear - CDTN, \\ Comissão Nacional de Energia Nuclear, \\ C.P. 940, 31123-970 Belo Horizonte - MG, Brazil
}

Received: November 18, 2004; Revised: April 6, 2005

\begin{abstract}
Quartz with aluminum as impurity absorbs energy from ionizing radiation and modifies its color. Colorless quartz becomes smoky or dark smoky (morion quartz) when exposed to gamma rays. By heat-treatment, smoky quartz may become successively greenish, yellowish, or brownish as the irradiation dose increases. Natural, colorless quartz is routinely colored by irradiation with gamma rays and heat-treatment for jewelry production. The color formation in natural quartz through this procedure is explained based on EPR, UV-VIS, and IR studies of irradiated and irradiated and heat-treated samples. Smoky quartz shows absorption bands in the visible region and a strong EPR signal. After heat-treatment it shows absorption bands in the near UV region with extensions into the visible region and a weak EPR signal. The intensity of the absorption bands is proportional to the irradiation dose. These changes of color are explained by the model of Itoh, Stoneham, and Stoneham. $\left[\mathrm{Al}_{\mathrm{Si}} \mathrm{O}_{4} / \mathrm{h}^{+}\right]^{0}$ centers are produced by irradiation, causing the EPR signal and the absorption bands in the visible region. $\left[\mathrm{Al}_{\mathrm{Si}} \mathrm{O}_{4}\right]^{-}$centers are created from $\left[\mathrm{Al}_{\mathrm{Si}} \mathrm{O}_{4} / \mathrm{h}^{+}\right]^{0}$ centers by heat-treatment. They cannot cause an EPR signal and have absorption bands in the near UV region with extensions into the visible region. The highest concentration of $\left[\mathrm{Al}_{\mathrm{Si}} \mathrm{O}_{4}\right]^{-}$centers occurs when the charge compensators have medium mobility. Lithium should give the best condition for color formation. Sodium (low mobility) and hydrogen (high mobility) should make smoky quartz colorless after heattreatment.
\end{abstract}

Keywords: natural quartz, color centers, irradiation, heat-treatment

\section{Introduction}

Natural or cultured quartz have usually a small content of aluminum as a substitute for silicon. It is well known that quartz with aluminum as impurity can absorb energy from ionizing radiation, e. g., gamma rays. This absorption of energy can influence its electromechanical performance ${ }^{1,2}$, themoluminescence ${ }^{3}$, as well as its color ${ }^{4-7}$. Detailed reviews of Al-centers in quartz have been provided by J. A. Weil $^{8}$ and L. E. Halliburton ${ }^{9}$. Colorless quartz becomes smoky or dark smoky (morion quartz) when exposed to gamma rays. Smoky quartz may become greenish, yellowish, brownish, or colorless after heattreatment. Natural, colorless quartz is routinely colored by irradiation with gamma rays and heat-treatment for jewelry production.

One observes that natural quartz shows absorption bands of light in the visible (VIS) and near ultraviolet (UV) regions after irradiation with gamma rays at temperatures from $290 \mathrm{~K}$ to $330 \mathrm{~K}$. The intensities of these bands increase with the dose. They can be removed by heat-treatment in air from $450 \mathrm{~K}$ to $630 \mathrm{~K}$. The bands in the visible region are removed before the ones in the ultraviolet region. It is possible to tailor the heat-treatment (temperature and time) to remove only the bands in the visible region. The absorption bands in the visible region cause the smoky quartz. The extensions of the near ultraviolet bands in the visible region cause the greenish, yellowish, and brownish quartz.

As a substitute for silicon, aluminum needs a charge compensator nearby, as $\mathrm{H}^{+}, \mathrm{Li}^{+}$, or $\mathrm{Na}^{+}$. The crystalline defect created by aluminum is denoted as a $\left[\mathrm{Al}_{\mathrm{Si}} \mathrm{O}_{4} / \mathrm{M}^{+}\right]^{0}$ center, where $\mathrm{Al}_{\mathrm{Si}}$ is an aluminum atom in place of a silicon one, and $\mathrm{M}^{+}$is $\mathrm{H}^{+}, \mathrm{Li}^{+}$, or $\mathrm{Na}^{+}$. The trapping of the proton at a non-bonding $\mathrm{p}$ orbital of an oxygen atom adjacent to the $\mathrm{Al}_{\mathrm{Si}}$ is related to bands at 3380 and $3310 \mathrm{~cm}^{-1}$ in the infrared (IR) spectrum ${ }^{10}$ of natural quartz observed at room temperature.
3367 and $3306 \mathrm{~cm}^{-1}$ are the same bands observed at low temperature. The reactions during irradiation are reported in the literature and are summarized in Table 1. Electrons are removed by gamma rays from the oxygen atoms adjacent to $\mathrm{Al}_{\mathrm{Si}}$. With an electron hole $\left(\mathrm{h}^{+}\right)$, the $\mathrm{Al}_{\mathrm{Si}} \mathrm{O}_{4}$ tetrahedron, denoted as $\left[\mathrm{Al}_{\mathrm{Si}} \mathrm{O}_{4} / \mathrm{h}^{+}\right]^{0}$ center, releases the $\mathrm{M}^{+}$to diffuse away in the quartz crystal lattice (1). The $\mathrm{M}^{+}$can combine with one electron (e $\mathrm{e}^{-}$) and becomes neutral at an interstitial position, $M_{i}$ (2). With sufficient thermal activation, electron holes can migrate, creating $\left[\mathrm{Al}_{\mathrm{Si}} \mathrm{O}_{4}\right]^{-}$centers $(3)$. The $\left[\mathrm{Al}_{\mathrm{Si}} \mathrm{O}_{4} / \mathrm{h}^{+}\right]^{0}$ center can also combine with electrons, creating $\left[\mathrm{Al}_{\mathrm{Si}} \mathrm{O}_{4}\right]^{-}$centers (4). These centers can attract one $\mathrm{M}^{+}$, coming back to $\left[\mathrm{Al}_{\mathrm{Si}} \mathrm{O}_{4} / \mathrm{M}^{+}\right]^{0}$ centers (5) or can combine with one electron hole, creating $\left[\mathrm{Al}_{\mathrm{Si}_{\mathrm{S}}} \mathrm{O}_{4} / \mathrm{h}^{+}\right]^{0}$ centers $(6)$. The irradiation can also ionize $\mathrm{M}_{\mathrm{i}}(7)$ or transform $\left[\mathrm{Al}_{\mathrm{Si}} \mathrm{O}_{4}\right]^{-}$centers in $\left[\mathrm{Al}_{\mathrm{Si}} \mathrm{O}_{4} / \mathrm{h}^{+}\right]^{0}$ (8) by removing electrons.

Ioth et al. ${ }^{3}$ attributed transitions of $3.3 \mathrm{eV}(380 \mathrm{~nm})$ to $\left[\mathrm{Al}_{\mathrm{Si}} \mathrm{O}_{4}\right]$ centers and $3.4 \mathrm{eV}(365 \mathrm{~nm}), 2.6 \mathrm{eV}(475 \mathrm{~nm})$, and $1.9 \mathrm{eV}(650 \mathrm{~nm})$ to $\left[\mathrm{Al}_{\mathrm{Si}} \mathrm{O}_{4} / \mathrm{h}^{+}\right]^{0}$ centers.

When the irradiation is interrupted, there can be a population of $\left[\mathrm{Al}_{\mathrm{Si}} \mathrm{O}_{4}\right]^{-},\left[\mathrm{Al}_{\mathrm{Si}} \mathrm{O}_{4} / \mathrm{h}^{+}\right]^{0}, \mathrm{M}^{+}, \mathrm{h}^{+}, \mathrm{e}^{-}$, and $\mathrm{M}_{\mathrm{i}}$. These centers are restricted to two boundary conditions. The sum of the populations of $\left[\mathrm{Al}_{\mathrm{Si}} \mathrm{O}_{4}\right]^{-}$and $\left[\mathrm{Al}_{\mathrm{Si}} \mathrm{O}_{4} / \mathrm{h}^{+}\right]$should be equal to the sum of the populations of $\mathrm{M}^{+}$and $\mathrm{M}_{\mathrm{i}}$ for conservation of the number of aluminum and charge compensator atoms. The sum of the populations of $\left[\mathrm{Al}_{\mathrm{Si}} \mathrm{O}_{4}\right]^{-}$and $\mathrm{e}^{-}$should be equal to the sum of the populations of $\mathrm{M}^{+}$and $\mathrm{h}^{+}$for charge conservation. Under these conditions, a situation could exist such that there are only $\left[\mathrm{Al}_{\mathrm{Si}} \mathrm{O}_{4}\right]^{-}$centers and no $\left[\mathrm{Al}_{\mathrm{Si}} \mathrm{O}_{4} / \mathrm{h}^{+}\right]^{0}$ or vice versa. Since the formation of $\left[\mathrm{Al}_{\mathrm{Si}} \mathrm{O}_{4}\right]$ - requires thermal activation, irradiation at low temperatures should produce almost only $\left[\mathrm{Al}_{\mathrm{Si}} \mathrm{O}_{4} / \mathrm{h}^{+}\right]^{0}$.

In this paper, a study of color formation in natural quartz through 
Table 1. Reactions during irradiation of quartz ${ }^{2}$.

\begin{tabular}{ll|l}
{$\left[\mathrm{Al}_{\mathrm{Si}} \mathrm{O}_{4} / \mathrm{M}^{+}\right]^{0}+\gamma \rightarrow\left[\mathrm{Al}_{\mathrm{Si}} \mathrm{O}_{4} / \mathrm{h}^{+}\right]^{0}+\mathrm{M}^{+}+\mathrm{e}^{-}$} & (1) & $\mathrm{M}^{+}+\mathrm{e}^{-} \rightarrow \mathrm{M}_{\mathrm{i}}$ \\
{$\left[\mathrm{Al}_{\mathrm{Si}} \mathrm{O}_{4} / \mathrm{h}^{+}\right]^{0} \rightarrow\left[\mathrm{Al}_{\mathrm{Si}} \mathrm{O}_{4}\right]^{-}+\mathrm{h}^{+}$} & (3) & {$\left[\mathrm{Al}_{\mathrm{Si}} \mathrm{O}_{4} / \mathrm{h}^{+}\right]^{0}+\mathrm{e}^{-} \rightarrow\left[\mathrm{Al}_{\mathrm{Si}} \mathrm{O}_{4}\right]^{-}+380 \mathrm{~nm}$} \\
{$\left[\mathrm{Al}_{\mathrm{Si}} \mathrm{O}_{4}\right]^{-}+\mathrm{M}^{+} \rightarrow\left[\mathrm{Al}_{\mathrm{Si}} \mathrm{O}_{4} / \mathrm{M}^{+}\right]^{0}+420 \mathrm{~nm}$} & $(5)$ & {$\left[\mathrm{Al}_{\mathrm{Si}} \mathrm{O}_{4}\right]^{-}+\mathrm{h}^{+} \rightarrow\left[\mathrm{Al}_{\mathrm{Si}} \mathrm{O}_{4} / \mathrm{h}^{+}\right]^{0}+365 \mathrm{~nm}$} \\
$\mathrm{M}_{\mathrm{i}}+\gamma \rightarrow \mathrm{M}^{+}+\mathrm{e}^{-}$ & (7) & {$\left[\mathrm{Al}_{\mathrm{Si}} \mathrm{O}_{4}\right]^{-}+\gamma \rightarrow\left[\mathrm{Al}_{\mathrm{Si}} \mathrm{O}_{4} / \mathrm{h}^{+}\right]^{0}+\mathrm{e}^{-}$}
\end{tabular}

irradiation and heat-treatment is reported, based on the model of Itoh et al. ${ }^{3}$. It is also proposed a role for the charge compensator in color formation.

\section{Experimental Procedure}

Samples of natural, colorless quartz from São José da Safira, Minas Gerais - Brazil were chosen because of the excellent colors they can develop. Slices of $10 \times 10 \times 1 \mathrm{~mm}^{3}$ were cut from these samples with the square faces perpendicular to the c crystal axis. The slices were polished with diamond paste up to $1 \mu \mathrm{m}$. They were irradiated in a Cobalt-60 Nordion GB-127 panoramic dry gamma irradiator to doses from $50 \mathrm{kGy}$ to $450 \mathrm{kGy}$. The temperature in the irradiation room was in the range of $290 \mathrm{~K}$ to $330 \mathrm{~K}$. After irradiation they were heat-treated in air in an oven with a transparent glass door to temperatures from $450 \mathrm{~K}$ to $630 \mathrm{~K}$ to become greenish, yellowish, or brownish. The heating rate was $20 \mathrm{~K} / \mathrm{min}$. The temperature at the sample position was measured with a thermocouple. The samples were removed from the heated oven at the moment of color transformation, which was detected by visual inspection. The temperature for the transformation of smoky to the final color depends on the dose ${ }^{11}$. These slices were used to perform the ultraviolet-visible (UV-VIS) spectrophotometry using a Shimadzu UV-2401 PC spectrophotometer (0.1 nm resolution), infrared spectrophotometry (IR) using an ABB Bomem Inc. MB 102 spectrophotometer $\left(4 \mathrm{~cm}^{-1}\right.$ resolution), and electronic paramagnetic resonance (EPR) measurements. The impurity contents were measured by EDS (JEOL Model JCXA 8900R), atomic absorption spectroscopy, atomic emission spectroscopy, and neutron activation ${ }^{12}$.

\section{Results and Discussion}

The chemical impurities in the samples were $\mathrm{Al}$ ( 80 to $100 \mathrm{ppm}$ ), Ti (4 ppm), Fe (22 ppm), Cr (1 ppm), Mn (2 ppm), Li (46 ppm), Na $(20 \mathrm{ppm})$. The aluminum content is not very higher than the sum of the lithium and sodium contents. This indicates that the samples are mainly lithium and sodium compensated. In the IR spectrum of the as-received sample there is a band at $3380 \mathrm{~cm}^{-1}$, showing that $\mathrm{Al}$ is also compensated by $\mathrm{H}$.

The near IR spectra obtained at room temperature from the samples (Figure 1) showed bands at 3595, 3486, 3433-3450, 3380, 3299 , and $3198 \mathrm{~cm}^{-1}$. According to $\mathrm{H}$. Bahadur ${ }^{13}$, the bands at 3300 and $3200 \mathrm{~cm}^{-1}$ are intrinsic Si-O stretching vibrational bands and are present in every quartz without exception; the 3595 band due to as-grown $\mathrm{OH}$ defects is not altered by sweeping; the 3476 band is $\mathrm{Li}$-dependent, because it can be produced by $\mathrm{Li}$-sweeping and removed by H-sweeping; the 3433-3450 bands are Na-dependent or $\mathrm{H}$-dependent. The 3380 band is usually attributed to $\mathrm{Al}-\mathrm{OH}^{14}$. We assigned the 3486 band as Li-dependent, the 3380 band as H-dependent, the 3433-3450 bands as Na-dependent or H-dependent, and the 3299 and 3198 bands as Si-O bond dependent.

After irradiation, the 3380 band grew and the 3486 and 3433-3450 ones reduced. After heat-treatment these bands showed a partial recovering. The other bands were not altered either by irradiation or heat-treatment. The growth of the 3380 band is an indication that the concentration of $\left[\mathrm{Al}_{\mathrm{Si}} \mathrm{O}_{4} / \mathrm{H}^{+}\right]^{0}$ centers is the high-

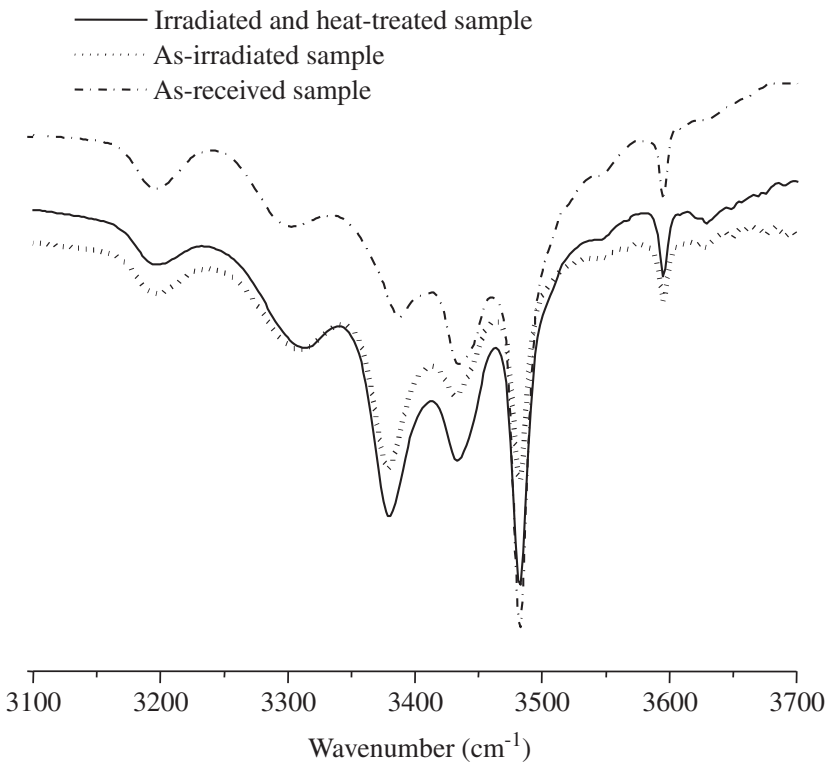

Figure 1. Infrared spectrum (transmittance) of as-received, as-irradiated (200 kGy), and irradiated and heat treated samples.

est in the irradiated sample and the lowest in the as-natural sample? The concentration of the Li-dependent centers decreased after irradiation, as evidenced by the decrease of the 3486 band. Bahadur ${ }^{13}$ also observed the reduction of the Li-dependent band in the natural quartz after irradiation at room temperature. He verified that only the band associated to the $\left[\mathrm{Al}_{\mathrm{Si}} \mathrm{O}_{4} / \mathrm{H}^{+}\right]^{0}$ centers grows after irradiation. Probably, protons are released from $[\mathrm{M}-\mathrm{OH}]$ defects together with the release of $\mathrm{M}^{+}$from $\left[\mathrm{Al}_{\mathrm{Si}} \mathrm{O}_{4} / \mathrm{M}^{+}\right]^{0}$ during irradiation to form $\left[\mathrm{Al}_{\mathrm{Si}} \mathrm{O}_{4} / \mathrm{H}^{+}\right]^{0}$ centers.

The UV-VIS spectra of the irradiated sample (Figure 2) showed a broad absorption band in the visible region. It can be decomposed in bands at $110 \mathrm{~nm}, 365 \mathrm{~nm}, 475 \mathrm{~nm}$, and $650 \mathrm{~nm}$ by a curve fitting $x^{2}$-test. The $110 \mathrm{~nm}$ is related to the $\mathrm{Si}-\mathrm{O}$ bond. The other ones are the transitions proposed by Itoh et al. ${ }^{3}$ for the $\left[\mathrm{Al}_{\mathrm{Si}} \mathrm{O}_{4} / \mathrm{h}^{+}\right]^{0}$ center. The strong EPR signal (Figure 3) observed for the irradiated samples is usually attributed to this center ${ }^{2,10}$.

The UV-VIS spectra for the irradiated and heat-treated samples (Figure 4) showed a band in the near UV region. It can be decomposed in bands at $110 \mathrm{~nm}, 280 \mathrm{~nm}$, and $380 \mathrm{~nm}$. The $380 \mathrm{~nm}$ band is proposed by Itoh et al. ${ }^{3}$ for the $\left[\mathrm{Al}_{\mathrm{Si}} \mathrm{O}_{4}\right]^{-}$center. We have also attributed the $280 \mathrm{~nm}$ band to this center, because it seems to be the main center after heat-treatment. The weak EPR signal of these samples (Figure 3 ) is attributed to a low concentration of $\left[\mathrm{Al}_{\mathrm{Si}} \mathrm{O}_{4} / \mathrm{h}^{+}\right]^{0}$ centers, since the $\left[\mathrm{Al}_{\mathrm{Si}} \mathrm{O}_{4}\right]^{-}$center has no unpaired electron and cannot contribute to this signal.

Considering the energy levels of the Al-centers taken from Table 1 and curve fittings, transitions in the near infrared region should also be expected: $1.1 \mathrm{eV}(1130 \mathrm{~nm})$ for the $\left[\mathrm{Al}_{\mathrm{Si}} \mathrm{O}_{4}\right]^{-}$center and $1.5 \mathrm{eV} 830(\mathrm{~nm}), 0.8 \mathrm{eV}(1551 \mathrm{~nm})$, and $0.7 \mathrm{eV}(1773 \mathrm{~nm})$ for the $\left[\mathrm{Al}_{\mathrm{Si}} \mathrm{O}_{4} / \mathrm{h}^{+}\right]^{0}$ center. We could not observe these transitions due to experimental limitations. 
The EPR measurements and the curve fittings of the UV-VIS spectra indicate that the irradiated samples have a high concentration of $\left[\mathrm{Al}_{\mathrm{Si}} \mathrm{O}_{4} / \mathrm{h}^{+}\right]^{0}$ centers whereas the irradiated and heat-treated samples have a low concentration. On the other hand, $\left[\mathrm{Al}_{\mathrm{Si}} \mathrm{O}_{4}\right]^{-}$centers are present in the irradiated and heat-treated samples. It seems that the irradiation induces the formation of $\left[\mathrm{Al}_{\mathrm{Si}} \mathrm{O}_{4} / \mathrm{h}^{+}\right]^{0}$. The heat-treatment transforms $\left[\mathrm{Al}_{\mathrm{Si}_{\mathrm{i}}} \mathrm{O}_{4} / \mathrm{h}^{+}\right]^{0}$ in $\left[\mathrm{Al}_{\mathrm{Si}} \mathrm{O}_{4}\right]^{-}$, probably through reactions (3) and (4) in Table 1 , while $\mathbf{M}^{+}$diffuses away. The longer the $\mathbf{M}^{+}$ions are separated from the $\left[\mathrm{Al}_{\mathrm{Si}} \mathrm{O}_{4}\right]^{-}$, the larger the population of these center after heat-treatment. The nature of the $\mathrm{M}^{+}$ion should be very important. If it has a high mobility, like the $\mathrm{H}^{+}$, it can significantly diffuse away from $\left[\mathrm{Al}_{\mathrm{Si}} \mathrm{O}_{4}\right]^{-}$. But it can also easily come back to its initial position and combine with these centers during the heat-treatment. If it has a low mobility, like the $\mathrm{Na}^{+}$ion, it cannot significantly diffuse

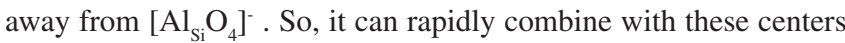
during heat-treatment. In both cases the quartz becomes colorless after heat-treatment. This could be an explanation for the Na-dependent or $\mathrm{H}$-dependent band behavior we observed. An ion of medium mobility,

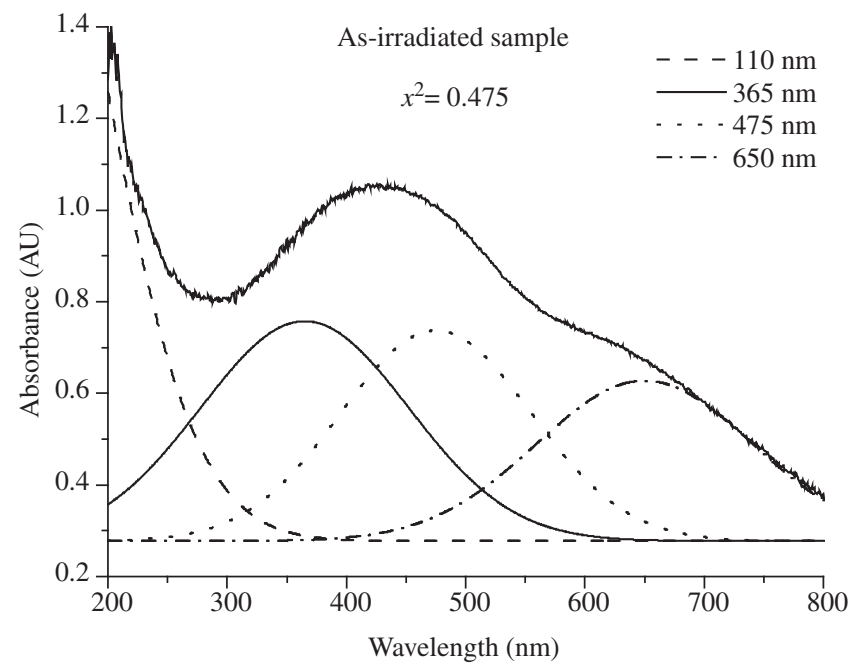

Figure 2. Curve fittings for UV-VIS spectrum of as-irradiated ( $80 \mathrm{kGy}$ ) sample.

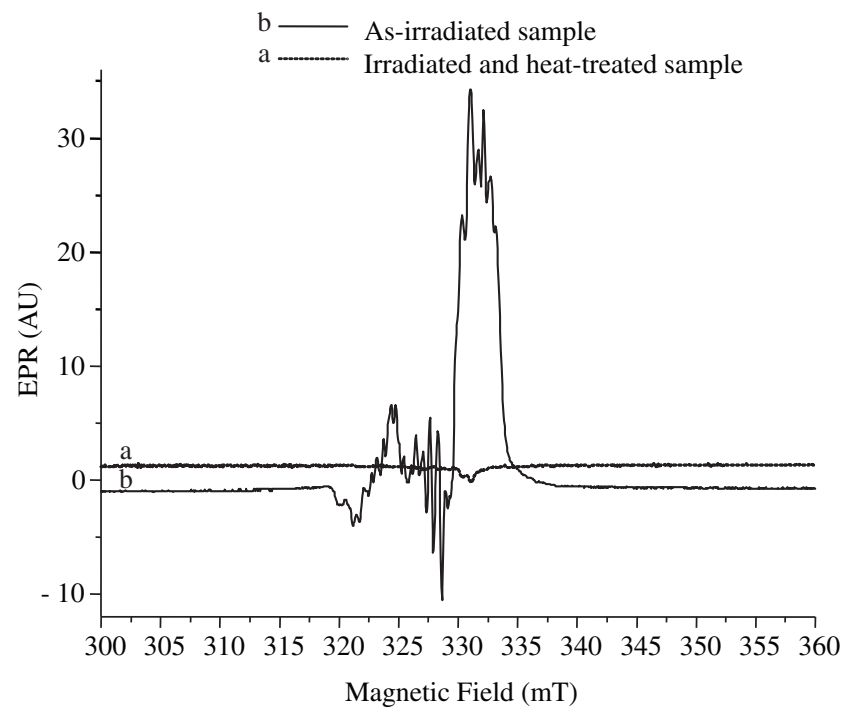

Figure 3. EPR spectrum from as-irradiated (200 kGy) and irradiated and heat-treated samples at $30 \mathrm{~K}$. like $\mathrm{Li}^{+}$, should give the best condition for the existence of a large population of $\left[\mathrm{Al}_{\mathrm{Si}} \mathrm{O}_{4}\right]^{-}$centers after heat-treatment.

Photons are emitted in reactions (4), (5) and (6) in Table 1. Some of them can be absorbed by $\left[\mathrm{Al}_{\mathrm{Si}} \mathrm{O}_{4} / \mathrm{h}^{+}\right]^{0}$ and $\left[\mathrm{Al}_{\mathrm{Si}} \mathrm{O}_{4}\right]^{-}$centers and re-emitted as $376 \mathrm{~nm}, 421 \mathrm{~nm}, 426 \mathrm{~nm}$, and IR photons. This can explain why one observes during heat-treatment the clearing up of smoky quartz with a blue luminescence.

$\left[\mathrm{Al}_{\mathrm{Si}} \mathrm{O}_{4}\right]^{-}$centers seem to be responsible for the color formation in quartz. The concentration of these centers after heat-treatment increases with the dose. For lower doses (less than about $70 \mathrm{kGy}$ ) the quartz becomes greenish. For medium doses (70 and $200 \mathrm{kGy}$ ) it becomes yellowish. For higher doses (higher than $200 \mathrm{kGy}$ ) it becomes brownish. This mechanism is depicted in Figure 5.

\section{Conclusions}

The small content of aluminum, usually found in quartz as a substitute for silicon, seems to be responsible for the color formation

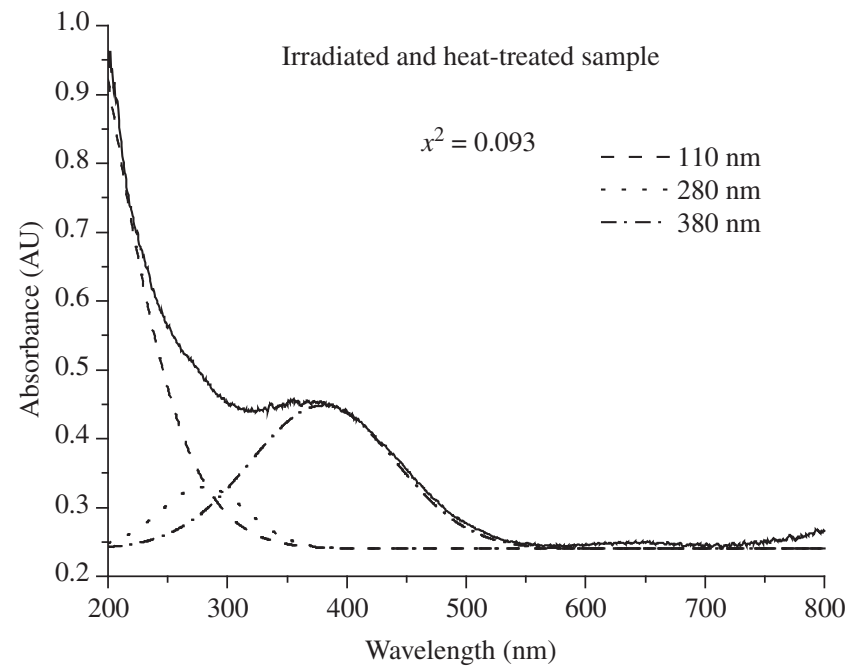

Figure 4. Curve fittings for UV-VIS spectrum from irradiated (80 kGy) and heat-treated sample.

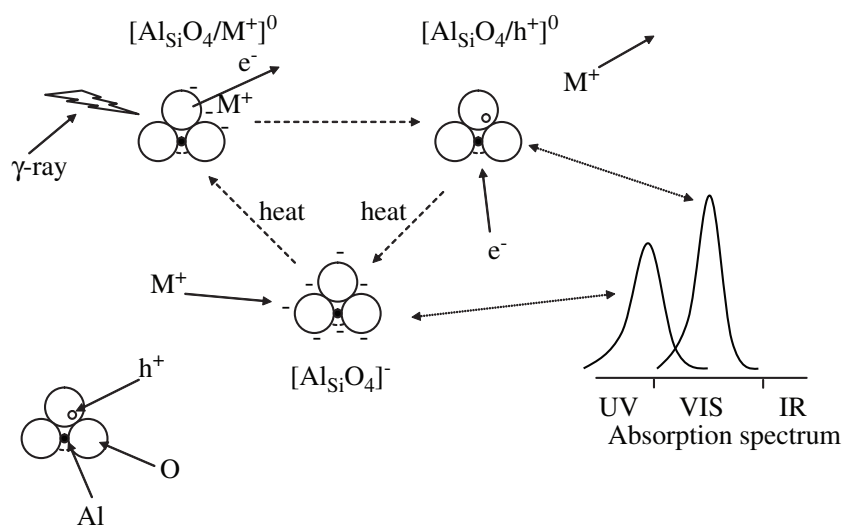

Figure 5. Mechanism of optical absorption in gamma irradiated and heattreated natural quartz. 
(greenish, yellowish, and brownish) after irradiation with gamma rays at $290 \mathrm{~K}$ to $330 \mathrm{~K}$ and heat-treatment from $450 \mathrm{~K}$ to $630 \mathrm{~K}$.

$\left[\mathrm{Al}_{\mathrm{Si}} \mathrm{O}_{4} / \mathrm{h}^{+}\right]^{0}$ centers are produced by irradiation. These centers have absorption bands in the visible region, turning the quartz smoky. $\left[\mathrm{Al}_{\mathrm{Si}} \mathrm{O}_{4}\right]^{-}$centers are created from $\left[\mathrm{Al}_{\mathrm{Si}} \mathrm{O}_{4} / \mathrm{h}^{+}\right]^{0}$ by heat-treatment. These centers have absorption bands in the near UV region with extension in the visible region, turning the quartz successively greenish, yellowish, and brownish as the irradiation dose increases.

The $\left[\mathrm{Al}_{\mathrm{Si}} \mathrm{O}_{4}\right]^{-}$center concentration and the color after heat-treatment depend on the mobility of the alkaline charge compensator. Lithium should give the best condition for color formation. Sodium and hydrogen should make the smoky quartz colorless after heattreatment.

\section{Acknowledgments}

The authors thank the financial support of CAPES, CDTN, and FAPEMIG. Walter de Brito, Wilmar Barbosa Ferraz, Luiz Oliveira de Faria, Klaus Krambrock, Estefânia M N Martins, and Ricardo Ferracini are kindly acknowledged.

\section{References}

1. Bahadur H. A brief survey of aluminum and alkali-related hydroxyl defects in quartz crystals and their radiation effects. Radiation Physics and Chemistry. 1998; 51(4-6):513-514.

2. Halliburton LE, Koumvakalis N, Markes ME, Martin JJ. Radiation effects in crystaline $\mathrm{SiO}_{2}$ : The role of aluminum. Journal of Applied Physics. 1981; 52(5):3565-3574.

3. Itoh N, Stoneham D, Stoneham AM. Ionic and eletronic processes in quartz: Mechanisms of thermoluminescence and optically stimulated luminescence. Journal of Applied Physics. 2002; 92(9):5036-5044.
4. Griffiths JHE, Owen J, Ward IM. Magnetic Resonance in Irradiated Diamond and Quartz. Report of the Conference on Defects in Crystalline Solids; 1954; London, UK. London: The Physical Society; 1954. p. 81-88.

5. Koumvakalis N. Defects in crystalline $\mathrm{SiO}_{2}$ : Optical absorption of the aluminum-associated hole center. Journal of Applied Physics. 1980; 51(10):5528-5531.

6. Nassau K. The origins of color in minerals. American Mineralogist. 1978; 63:219-229.

7. Rossman, G. R. Colored varieties of the silica minerals. Reviews in Mineralogy. 1994; 29:433-467.

8. Weil JA. Review of Electron Spin Spectroscopy and Its Application to the Study of Paramagnetic Defects in Crystalline Quartz. Physics and Chemistry of Minerals. 1984; 10(4):149-165.

9. Halliburton LE. ESR and Optical Characterization of Point Defects in Quartz. Applied Radiation Isotopes. 1989; 40(10-12):859-863.

10. Kats A. Hydrogen in $\alpha$-Quartz. Philips Research Reports. 1962; 17:133-195.

11. Nunes EHM, Lameiras FS. Estimativa da dose do quartzo natural irradiado pela termoluminescência. REM - Revista Escola de Minas. 2004; 57(1):19-22.

12. Alfassi ZB. In: Meyers RA, editor. Encyclopedia of analytical chemistry. Chichester: John Wiley \& Sons, 2000. p. 12497-12526.

13. Bahadur, H. Infrared Characterization of Natural and Cultured Quartz: The Effect of Electrodiffusion and Irradiation. Journal of Applied Physics. 1989; 66(10):4973-4982.

14. Hashimoto T, Yamaguchi T, Fujita H, Yanagawa Y. Comparison of infrared spectrometric characteristics of $\mathrm{Al}-\mathrm{OH}$ impurities and thermoluminescence patterns in natural quartz slices at temperatures below $0{ }^{\circ} \mathrm{C}$. Radiation Measurements. 2003; 37(4-5):479-485. 